\title{
PHILOSOPHICAL THEISM OF PETER LINITSKY
}

\author{
Natalia Mozgova \\ National Pedagogical University imeni M .P. Drahomanova
}

P. Linitsky is a typical representative of the Kiev school of philosophical theism, a philosopher deeply religious, able to find value guidelines in the Christian spiritual tradition, the critical thinking of which is organically combined with intellectual tolerance. G. Shpet, the researcher of the history of Russian philosophy of the first quarter of the twentieth century noted, "in the general movement of our philosophical thought, the aforementioned question (the correlation of faith and knowledge - N. M.) was destined to occupy only a subordinate place, since it, as a particular issue of the Orthodox faith and European knowledge, became a more significant problem for us and at the same time specific. But in one of the trends of our philosophy, he naturally took a dominant place: in the philosophy of Orthodox theological academies" [9, p. 369-370]. One of the dominant places this issue occupied in the creative heritage of P. Linitsky. In this connection, the thinker's conclusions regarding the main tasks of philosophy acquire new content. As noted above, Linitsky sees them in solving two problems: 1) in creating a scientific philosophy, and 2) in reconciling science with religious faith, or in the ratio of faith and knowledge.

How does Linitsky solve the last question? In any case, in order to correctly judge the position taken by the philosopher, one must consider his views in full. And then the image of a thinker will open up before us, for which reflection on the subject of faith was not a simple and fascinating argument, but an essential need for his inner life. Note that the theological and philosophical views of P. Linitsky were inherent more spiritual than religiosity. And in everyday life, according to the memoirs of his contemporaries, "church and liturgical rites were not for him what they were for a believing coal miner; he remained a Philosopher in the temple: the temple environment created a mood of closeness to the Absolute Spirit, the reflection on which was an essential moment of his philosophizing. The Eucharist was for him an act of the closest unity of the human spirit with the Absolute Spirit, but the subtleties of dogmatic disputes always seemed to him insignificant and inconsequential" [2, p.758].

The most scrupulous and consistent question of the relationship between faith and knowledge is considered by Linitsky in his fundamental work "The Importance of Philosophy for Theology (A. Handbook for Apologetic Theology)” (1904). And although the Kiev philosopher always made a clear distinction between theology and philosophy, in this work he most clearly appears as a theologian and philosopher at the same time. If we proceed to the thinker's thoughts on the subject of faith, the philosopher first of all believes that "between faith as the acceptance of a ready truth and scientific research, the purpose of which is to know the same truth, the difference is not absolute, but only relative ... The need for scientific research is not limited to faith, but, on the contrary, is required by it. With a complete and comprehensive knowledge of the truth, faith itself would be superfluous. Faith 
is always in unity with hope, and hope is hope and the completion of all that is imperfect" $[4$, p. 71$]$.

According to the thinker, the question of the relationship between faith and knowledge in the history of mankind arose and will continue to arise not because it is insoluble, but primarily because the content of this issue changed in different historical periods. "The question of the relationship between the mind and Revelation, knowledge and faith, between philosophy and theology cannot be resolved once and for all. On the contrary, this question requires a special solution for each time, corresponding to the spirit of that time, the state of development of science, education, needs and living conditions" [7, p. 510].

The philosopher defends the idea that in the era of the Fathers of the Church on faith and knowledge were decided depending on the circumstances at the time: it was necessary to define the relationship of the new faith to paganism. The fathers of the Church were not able completely to neglect the importance of paganism and sought to repel the attacks of pagan philosophers on Christianity. At the same time, according to the philosopher, the greatest influence on the decision of this question had the philosophy of Plato. The middle ages knew no other philosophy except the philosophy of Aristotle and the natural Sciences did not exist. And so the question about faith and knowledge has acquired a different kind namely, how to reconcile between Christian dogma with Aristotelian philosophy. Such coordination, as it is known, was best achieved by Thomas Aquinas. Continuing his reasoning, Glinicki comes to the conclusion that the effect of the French revolution was the initiation of the European peoples' desire for national identity, because the main factors of political life began to admit national origin. According to the thinker, the philosophers of that time tried to reconcile these principles with universal ideas, and the main forms of expression of universal principles recognized science and art.

Proceeding further, from the object of his study, Glinicki builds consistently the same paradigm relative to what was then Russia. The question of the relation of faith and knowledge most clearly, according to the Kyiv philosopher presented in the views of Westerners and Slavophiles. Westerners have proved that only scientific and aesthetic education can engage Russia in a common human life and to free it from rigidity. They believed that it was of such a nature rigidity was a life in ancient Russia. Slavophiles saw the basis and the guarantee of the national identity of Russia in merging Orthodoxy with people's lives. That is, loyalty to Orthodoxy is a most important feature of the national character, and as this belief is universal, it has a universal significance. In the opinion of the Slavophiles, that Russia hosted a happy coincidence of national principles with universal elements.

The philosopher argues that the Slavophiles understand faith in the spirit of SellingHegelian philosophy, and consider this issue in the socio-political aspect. That is, national identity recognized as a major factor of socio-political life. "Today - says the philosopher, the question of the relation of faith and knowledge, received a new look. This issue is discussed not from the socio-political, and natural scientific point of view. Not about the relationship of national and universal now you can go bickering (as the Slavophiles and Westerners), and about the relationship of natural and supernatural. All natural is relegated to the domain of scientific knowledge, and the supernatural is a matter of faith" [4, p. 122]. 
Unacceptable for the thinker is the position that belief in supernatural lies outside the scientific sphere, and nothing to do with the science has. From this point of view, the belief in the supernatural is nothing like superstition, which sooner or later must disappear and to give way to new knowledge. The philosopher believes that such reasoning is empty and meaningless, because, first of all, you need to pay attention to whether there is an overall indisputable concept of natural. Linitsky puts in this connection a question: whether there can be in General, the question of the relationship between the natural and the supernatural problem of natural history, and isn't it rather a problem of philosophy? The philosopher is deeply convinced that "the element of faith required in science as the belief in the truth... whatever changes never experienced science in its later development, it would not have expanded the scope of scientific knowledge, never a science not addressed the need for religious faith because the Foundation of religious belief is contained in the nature of the human mind" [4, p. 125]. This explains the deep religious philosopher of such great scientists as Copernicus, Galileo, Kepler, Newton.

According to P. Linitsky, if indeed there was such a strong contrast between knowledge and faith, then it would be neither in life nor in the consciousness of the individual would not be able to live with these opposites and at the same time to form one whole character of a person. At the same time the thinker notices that the Bible cannot be the source from which you want to borrow the grounds for the resolution of scientific issues, and is in the first place, absolute value for the believer, as it embodies the doctrine of God and doctrine of salvation of the human soul: "the two characteristics - relationship to God and to salvation of the soul, and constitute the essential criteria that should serve as a Foundation for distinguishing mandatory truths of faith from simple thoughts that can be taken but may not be recognized depending on whether they agreed or not with the faith, and justified by whether or not they have current state specific Sciences" [8, p. 69]. Linitsky defends the idea that religion can be a means to meet the thirst for knowledge, because in this case the religious doctrine becomes a source of different thoughts. If later research come into conflict with these thoughts, then, an inevitable negative consequence of a collision between science and religion: "To avoid this, a clear distinction between dogmatic truth and religious thoughts that may not have the required values for the believer, and which do not embody the true faith" [5, p. 7]. Thus, Glinicki comes to the conclusion that the latest advances in scientific knowledge more convincing evidence of the necessity of belief in the supernatural in General, and to justify religious faith, recognizing its eternal spiritual need of the individual and humanity in general.

From the above reasoning P. Linitsky it becomes clear that the philosopher does not refuse faith in scientific knowledge, but simultaneously insists on the importance of the mind in faith: "Those who would like to lose entirely excludes all in the matter of faith, obviously, require essentially that does not to think about the subject of faith, but in a way these items can become quite alien to our thinking. Only thanks to the constant discourse on the subject of faith, he becomes close with our soul acquires the power over the secret of its movements" [4, p. 61].

Further, the philosopher argues that the importance of studying the problem of faith is expressed in the support, protection and the justification of religious belief, such as personal 
beliefs, which fundamentally affects the whole inner world of man. Thinker sure, that in itself is a scientific study does not contain anything opposite to the tenets of the faith. But the other thing is that those scientific results and conclusions that result from these studies. They led in human history to clashes between science and religious faith. Again, these clashes are not so much depended on the scientific and religious provisions, but from a particular interpretation. At different times the concepts of science have changed, and science, according to the philosopher, because of the differences of their objects, goals and methods led to different interpretation of purely scientific knowledge. The question of the relationship between knowledge, the highest achievement of which is the philosophy and belief of the truth which is the content of the positive theology was solved by P. Linitsky similarly, the solution of the question of the relationship between philosophy and concrete Sciences. Philosopher and theologian working in their field, approach the solution of the question of the relationship of faith and knowledge within their own research. Philosopher reveals the formal definition of the idea of unconditional, while the theologian defines the content of these definitions. Thus, the unity of the faith and knowledge: faith finds in constructions of reason formal basis for his detention, and the mind turns to faith, following the completion of its formal concepts about God. The fact that the "rational concept of God, like all other concepts created by the mind, are only formal. So this concept could be an expression of real beings, it is necessary the revelation of this creature, revealing its active side as we do this partially in the usual way in nature, and the extraordinary way in history; Revelation is, thus, necessary to justify the imperfections of the formal concept of the mind of God" [8, p. 70-71].

The Thinker also believes that the relation of philosophy to religion is due to the fact that any religion always contains in itself theoretical ideas about the Divine, about the world and about man; thus, in any religion there are foundations of a more or less holistic worldview. From this it is clear that philosophy naturally borders, and often coincides with religion. The main sign of their distinction is that philosophy has reason as its foundation and therefore always recognizes as its achievements only those opinions that are obtained through logical reasoning. Linitsky further emphasizes that, although the existence of such trends in the history of philosophy as mysticism contradicts this position, its representatives are not able to completely deny the significance of reason in the knowledge of truth. Often coinciding with religion, philosophy still always tried to clear religious ideas of everything incomprehensible and surprising, to elevate them and make them more or less understandable (this was the case in paganism in ancient Greece), or, on the contrary, tried to rise to the height of religious contemplations on the basis of a holistic system of concepts (this was the case in medieval and partly in the philosophy of the New Age in relation to Christianity). The philosopher concludes that if "before philosophy was a servant of theology, now, in fairness, philosophy can be called an assistant to theology? [4, p. 86].

The main task of religion thinker saw in the moral education of people, support their sense of duty, love of truth. For this we need faith, purity, integrity of heart, which strengthen the human spirit, gives man a moral and ethical sense. P. Linitsky emphasizes that philosophical system, which renounced the theistic worldview, unable to justify their moral ideas, and inevitably sinking to the principles of eudaemonism (coarse or refined), because in 
any way it is impossible to prove that the pursuit of happiness alone can make man moral creation: "...on the Contrary, and the happiness of all its value will only be that moral dignity, which is the purpose of absolute and unsubordinated anything" [3, p. 163]. P. Linitsky believes that faith is a positive state of mind and its a certain mood, which affects behavior, and in General all human life and have an educational impact. And unbelief, as a simple lack of faith - there is an emptiness of the soul, but because if can affect human behavior, it is only destructive way. On a deep belief of the philosopher, theism should be recognized not only psychologically necessary but reasonable philosophical system, because "if indeed for a thinking man there were no theoretical foundations that would justify theism, then it would be possible and even necessary to admit that a man may be entirely religious only as long as thinking is purely philosophical, and if you do not have the ability to systematic and scientific thinking" [6, p. 185].

Thus, as a typical representative of Kyiv ecclesiastical-academic philosophy, P. Glinicki, as shown above, the need to justify religious faith, but at the same time was opposed to any religious fanaticism. The thinker does not refuse faith in scientific knowledge and the value of reason to faith. His theological-philosophical system was generally rationalistic in nature, and therefore the philosopher spoke firmly opposed to empirical methods in theology, which were based on historical and psychological experience and experiment. " $A$ fundamental error of modern seekers of faith in that, - said the philosopher, - that they look to religion as to science, Christianity as a kind of philosophy, and Jesus Christ as usual, next to the other, the founder of the religion ....and in the mind as the sole means of returning the lost of faith" [4, p. 76].

From the estimates which were given by his contemporaries the theological and philosophical system of P. Linitsky, it becomes clear that it is partly considered a representative of the theological rationalism or speculative theology. This is evidenced by at least the analysis of the theistic systems P. Linitsky, which was given by Professor D. Bogdashevsky. Bogdashevsky called philosophical system of P. Linitsky "healthy metaphysics", considering that the unity of faith and knowledge is reached Lipnickim with his appeal to the "speculative theology, where religious ideas are explained in a rational manner, or are reduced to the basic concepts of the mind" [1, p. 126-127]. However, this did not prevent D. Bogachevska to appreciate the creative legacy of P. Linitsky, indicating that "Linitsky quite deep and original thinker" [1, p. 138]. works which "contribute to the creation of a truly Christian worldview in General and Christian philosophy, and thus blow up the foundations for any erroneous opinions" [1, p. 125]. Similar thoughts with prudence and delicacy of the language of the obituary will Express later Professor of the Academy p. P. Kudryavtsev. He particularly noted that "unshakable faith in the existence of the Absolute spirit and in the immortality of the human soul encouraged P. Linitsky often seek clarification of the question of the relationship between faith and knowledge and to disclose the speculative foundations of Christian theology». And further, he will stress that «methodological principles of speculative theology will not prevent the Christian theology, since the content of the Christian faith is in harmony with the a priori principles of the mind" [2, p. 759-760]. 


\section{Список використаних Ажерем}

1. Богдашевский А.И. ЗАравая метафизика Трудъ КАА. 1894.- Т.2. Кн.5 С. 125-138.

2. Кудрявцев П.П. Профессор Петр Иванович Аиницкий. Некролог Трудъ КАА. 1906. T.2. Кн.6. С. 737-771.

3. Аиницкий П.И. Ава конца (Конец 18 и конец 19 веков). По поводу книги проф. А.Н. Гилярова «Предсмертные мысли 19 века во Франции. - К.,1901. Труды КАА. 1901. T.2. C. 151-178.

4.Аиницкий П.И. Значение философии Аля богословия (Пособие к апологетическому богословию) Чтения в Церковно-историческом и археологическом обшестве при КАА. 1904. Вып.5. С. 71-195.

5. Аиницкий П.И. Критика начал философии. Абсолютное есть ми идея, или же действительное существо? Вера и разум. Харьков, 1890. Т.2. Ч.1. С. 1-27.

6. Аиницкий П.И. О необходимости метафізики. Вера и разум. Харьков, 1897. Т.2. Ч.1. С. $1-24 ; 49-76 ; 183-200 ; 231-244$.

7. Аиницкий П.И. О православии, как истинно христианской вере. Bepa u разум. Харьков, 1897. Т.2. Ч.2. С. 503-525.

8. Аиницкий П.И. Пособие к изучению вопросов философии (элементы философского миросозерцания). Харьков, 1892. 425 с.

9. Шпет Г.Г. Очерк развития русской философии. - СверАловск: ИзА-во Урал. ун-та, 1991. C. 217-578.

\section{References}

1. Bogdashevsky D.I. Sound metaphysics Proceedings of the KDA. 1894.- T.2. Book 5, pp. 125-138.

2. Kudryavtsev P.P. Professor Peter Ivanovich Linitsky. Obituary Proceedings of the KDA. 1906.V.2. Book 6. P. 737-771.

3. Linitsky P.I. Two ends (Late 18th and late 19th centuries). Regarding the book of prof. A.N. Gilyarova "The dying thoughts of the 19th century in France. - K., 1901. Proceedings of the KDA. 1901.V.2. P. 151-178.

4. Linitsky P.I. The Importance of Philosophy for Theology (A Guide to Apologetic Theology) Readings in the Church-Historical and Archaeological Society at the KDA. 1904. Issue 5. P. 71-195.

5. Linitsky P.I. Criticism of the beginnings of philosophy. Is there an absolute idea, or is it a real being? Faith and reason. Kharkov, 1890.V.2. Part 1. P. 1-27.

6. Linitsky P.I. About the need for metaphysics. Faith and reason. Kharkov, 1897.V.2. Part 1. P. 1-24; 49-76; 183-200; 231-244.

7.Linitsky P.I. About Orthodoxy, as a true Christian faith. Faith and reason. Kharkov, 1897.V.2. Part 2. P. 503-525.

8. Linitsky P.I. A allowance for the study of philosophical issues (elements of philosophical world outlook). Kharkov, 1892. 425 p. 
9. Shpet G.G. Essay on the development of Russian philosophy // Vvedensky A.I., Losev A.F., Radlov E.L., Shpet G.G. Essays on the history of Russian philosophy. Sverdlovsk: Publishing House Ural. University, 1991.S. 217-578.

\section{Відомості про автора: \\ Мозгова Натамія Григорівна}

mozgova@gmail.com

Національний педагогічний університет імені М.П. Арагоманова

вул. Пирогова 9, м. Київ,

01601, Україна

ORCID: https://orcid.org/0000-0001-9464-9852

Information about the author:

Mozgova Natalya Grigorivna

mozgova@gmail.com

National Pedagogical University imeni M.P. Drahomanova

Pirogova St. 9, Kyiv,

01601, Ukraine

ORCID: https://orcid.org/0000-0001-9464-9852 


\section{P.I. Linitsky}

\section{THE IMPORTANCE OF PHILOSOPHY FOR THEOLOGY (HANDBOOK FOR APOLOGICAL THEOLOGY) ${ }^{1}$}

\section{Question of faith and knowledge (Slavophilism and Westernism)}

There were many disputes between Slavophilism and Westernism, but these disputes, apparently, did not lead to anything decisive. For the very opposite that was between Slavophilism and Westernism still remains in force. Meanwhile, it would seem that any reasonably posed question must certainly get a satisfactory solution. If the question is of such a nature that it cannot be resolved, then sooner or later it must be explained why it cannot be resolved.

So, the question is, the question was the chief subject of disagreement between Westernism and Slavophilism whether any particular decision? There is no doubt that Westernization advocated science and Slavophilism were fought in the defense of religious faith, but because the dispute was concerned, obviously, about faith and knowledge. This question, as we know, not new, on the contrary, very old. And if this question arises again and again requires a permit, after so much work is necessary to permit it, it happened and is happening not because the question is insoluble, but because, mainly, what has changed at different times the concepts of faith and knowledge. Because of this, the meaning of the question was different and therefore the previous decision were not sufficient. For example, in the era of the Holy fathers on the formulation and solution of the question of faith and knowledge was mostly influenced by Plato's philosophy. In the middle ages, reasoning about belief and knowledge, under the name of knowledge, science, understood mainly the philosophy of Aristotle; and here Thomas Aquinas satisfactorily decided the question in this sense, joining in the system of the Church's dogmatic definitions to the concepts of Aristotelian philosophy. Slavophiles we have understood the faith, partly in the spirit of selling-Hegelian philosophy, and more importantly, applied to the question of the knowledge and belief of the socio-political point of view. The consequence of the French revolution, which destroyed the foundations of medieval life, was the awakening of European peoples desire for national identity. Beginning of nationality everywhere have come to recognize the main basis of socio-political life. Realizing the importance and necessity of beginning to start to Refine and elevate, philosophers have sought to link him with the ideas and objectives, relevance of the universal and universal. It was claimed that only one nationality can reach important values in communication the history of mankind, which will be started on the universal, and the main forms of consciousness and expression began admitted of universal science and art. Westerners, following this current of thought, argued that only scientific and aesthetic education can introduce us to human life (and such is the life of the European peoples, as the most enlightened) and to save us from the covers of a narrow nationalism. Believed that that covers exclusion represents life in Ancient Russia. Slavophiles pointed out,

1 Аиницкий П.И. Значение философии Аля богословия (Пособие к апологетическому богословию). Чтения в Церковно-историческом и археологическом обществе при КАА. 1904. Вып. 5. С. 71-195. 
as it is known, that the Orthodoxy we have merged with the people's life, so, in all fairness, we can look at our Orthodoxy, as the key base and the key to our national identity. The only thing it can save us from de-identify; this is evident from the fact that broken relationship with Orthodoxy as a national faith, cease to be Russian people. Indeed, the phenomenon is absolutely the opposite of what we see in the West. There the German people, for example, found for the first time on their nationality and provided for further expansion in the spirit of nationality only after he separated from the Catholic Church. It is remarkable that in the West in those areas, which have the advantage of universal importance, in science and in art, manifested hostile attitude to the Church, however, and to the faith. Protestantism separated from the Catholic Church, have lost the character of the Church, along with the faith and here also gradually weakened. Our people's life with different character differs in this respect. As the Orthodox have become the basis of national life, and Orthodoxy - the faith of the Catholic, universal, so has the nature and value of human beginning, it is clearly that we had a happy combination of nationality beginning with the elements of the universal. Faithfulness to Orthodoxy for us is the most important trait of the national character, however, the same Orthodoxy determines our vocation in the future - to preserve the Christian faith in its integrity to all mankind, that is to carry out the ideal of the Christian life, and thus lead to unity and mutual spiritual harmony of all Nations, all mankind. This is the vocation of the Russian people according to the ideas of Slavophilism. So, it turns out that in addition to the even science is universal, that is, the high and multiple value in shared history, for our people secured simply by the fact that it is the Orthodox people, that is the unchangeable loyalty of his Christian ideal of life. The need for scientific education according to the teachings of the Slavophiles, it is not excluded, but only raises the requirement that the education is consistent with traditional Orthodox spirit. This means that, borrowing science from the West, we must be careful not to impose on the people of alien concepts and ideals, is entirely taken from the life of Western peoples. We need to wait patiently to the people of our himself, as the development in it mental independence, left its mark on science, and to thus develop in us over time, not only almost religious enlightenment, which, however, our nation has long already had, but also scientifictheoretical, and, moreover, the last in complete harmony and spiritual unity with the first. Thus, the main task of our enlightenment, by definition of Slavophilism, is to gradually develop a synthesis of scientific knowledge with religious faith and, moreover, this synthesis, which would have universal importance, not just national. Although themselves Slavophiles and some of slavjanofilstvo writers worked on the solution of this extensive task, however, the solution it must be recognized far in the future, because you must first prepare the data, which must be based the solution of the aforesaid task. This data includes well-established, either side which meets with the objection itself, and therefore universally accepted, understanding of Orthodoxy. Who's to say that we already have such an understanding of Orthodoxy? But this is only one element of the task. The other element is scientific knowledge. But on this subject there is recognized, in all its parts is firmly established and systematic concepts. The concept of scientific knowledge at different times varies, depending on what science dominate and define themselves the nature of enlightenment. Science humane contain many elements of the perfect operating on the human spirit, 
uplifting, moralistic way. Therefore, in the humane Sciences have the most favorable conditions for the implementation or achievement of the synthesis of religion with science education. The advanced European Nations had the good fortune to survive the difficult, but fruitful, long period of humane education, which is so firmly established in life and so deepened the spirit and manners of European humanity that, despite all the pretentious and even abuse, which has long been marked Catholicism, despite the complete lack of unity and internal harmony in Protestantism, than the religious sense often (in life and in literature) is an amazing vitality and strength. We have, unfortunately, humane education began to spread in the time when in the West the prevailing value was to go on the side of science. As a result, instead of classicism, the natural sciences should have prevailed in our country as well: a) the natural sciences are easier to assimilate, at least to assimilate them it does not require such a high level of mental talents as is required for humane education; b) our social and popular life, as it turned out with particular obviousness to everyone after the Crimean War, was so unsettled that it was necessary to immediately start planting European culture in our country, and it was mainly necessary to ensure material progress, and this area of interest It is closely connected with the natural sciences, which were before, but now in particular (due to many inventions) they are the root engines of material progress. It is clear that we have even more than in the West, the influence of science on the minds should have become predominant, because we do not have such traditions in the field of scientific education, such an inheritance that would somehow balance this influence.

And now, because of this influence, the question of faith and knowledge again gets a new look. Now this question must be considered from a socio-political point of view, and natural science. Not about the relationship between national and universal now may be a dispute and a disagreement (as the Slavophiles and Westerners), and about the relationship between the natural and the supernatural. All-natural leaves in the area of scientific knowledge and research, and the supernatural is a matter of faith. Science, they say, anything supernatural does not know and does not recognize. Therefore, the belief in the supernatural lies outside the scientific field and nothing to do with science has. The belief in the supernatural from the point of view of the so-called scientific, that is, a positive attitude, is a legacy of those distant times, when science in the proper sense was not, when scientific knowledge about nature, all about the natural order of things, did not exist. It turns out that the belief in the supernatural is nothing like superstition, which sooner or later must disappear and to give place to knowledge. To see how such arguments are empty and unfounded, it should, first of all, pay attention to whether we have firmly established and indisputable concept of natural, and there is this business of natural science to develop concepts about the natural and the supernatural, is it not rather the task of philosophy? Do science also has its own philosophy, including the study of basic concepts used in the natural Sciences. Such, for example, the concept of laws of nature. Before the natural was defined as agree with the laws of nature, and the supernatural was understood as contrary to the laws of nature (e.g., miracles). But the very concept of laws of nature in this case was problematic and caused doubt. Not that that it is impossible to claim that science knows all the laws of nature, and the seemingly contradictory laws of nature may be then quite natural and existing or occurring according to a certain law of nature. But it is important if you can recognize the 
notion of laws of nature edge concept, then whose scientific explanation should not rise? Common sense says that if you understand the laws of nature as rules which occur the phenomena of nature, and so they usually are understood, it is quite inconceivable that the laws of nature by themselves and through themselves existed, there would be not conditional, but absolute value. If nature follows rules, that there must be a reason that established and maintains these rules. And the reason for this, as standing above the rules or laws of nature must be supernatural. Here is natural-scientific philosophy faces the same insurmountable difficulty for her, with what had to deal of philosophy after Kant in the opposite relation established by the philosopher between the thing in itself and phenomena. Only phenomena are knowable. However, it is necessary to prevent the thing in itself, that is, what lies beyond phenomena and what is not knowable. As closely associated with the concept of natural concept of the supernatural; the latter is necessary for the first border. To resolve the difficulty connected with understanding the laws of nature, as a rule, other otherwise define the law of nature. They say that the law of nature is uniformity, on the one hand, in the order of phenomena, and their jointness - the monotony inseparable from the events themselves, as a fact established on the basis of observation and experimental study of the phenomena of nature by itself taken the monotony, in the order and combination of phenomena is an abstract concept and, therefore, subjective. We only know that natural events happen, usually in this order, or this, rather than another combination, but we can't say that the same phenomena, under no circumstances, can not occur in different combination, in different order. This notion of laws of nature more conducive to the assumption of the supernatural along with the natural. Because the supernatural, in accordance with the specified now understanding the laws of nature, will consist only in a different order and a different combination of phenomena, in combination, different from the usual. The possibility of a different order and different combinations of phenomena, as it is written, should not be denied. The use of the concept of the laws of nature science is now less demanding and is more modest in comparison with the same time. But as for the research method, it is still not been given any value of the speculative method, and in fact denied metaphysical philosophy. Also in relation to phenomena of the spiritual life of man the only suitable research method is considered to be experienced, even experimental study. It is assumed that the unity method is approved and provided by the unity of science. But there is actually this unity, is it possible? You can't hide the fact that a profound difference exists between natural science, on the one hand, and the history of mankind on the other. The difference is it is not that the content of the story are seemingly isolated facts, individual objects, events, and content abstract the natural Sciences are the General relationships of phenomena. The story is not limited to description, but expresses the estimation of what the required standards. And where to get these standards? Only speculative philosophy is able in a scientific way, through research, to establish concepts that have the meaning of norms. Among these concepts are the concepts of the supernatural, to the rational justification of which the weak attempt was made above. However, an element of faith is necessary in science, namely faith in truth (the postulate of reason according to Kant). Scientific knowledge is limited to a simple description of the facts and formulas expressing their constant repetition. In this case, science cannot guide human behavior, and this must be left 
to faith.

The question of faith and knowledge is theoretical, therefore, concerns the theoretical side of religious faith, namely her relationship to science. There were many experiments of the agreement different points of the Christian faith with the academic regulations. But much more important than resolution in a conciliatory spirit of personal questions to establish the principle of the necessity of religious faith, it is faith in the existence of the supernatural from a scientific point of view. In our treatise on the belief in the supernatural made the experience a solution to this issue. The conclusion brings this experience to clarify the need for religious faith, is the one that no matter what further changes may be tested by science, no matter how expanded the scope of scientific knowledge, never a science will not be abolished the need for religious faith, as many believe, because the basis of religious faith is the substance of the human mind. Shown above, and the latest science for his research gives a clearer only to see the grounds, consisting of three basis, what are the being, life and mind. The last beginning is particularly important that humane science, as a disclosure of the mind of man, and through him come into the relationship with science, and why the question of the relationship of faith and knowledge is subject to dual coverage. From the point of view of natural science, which, on the basis of the theory of evolution tries to fill in the gap that separates the mind from the irrational, alive from the dead, but as we saw in vain, and then - from the point of view of humane science, but as a start this was supposed in classical antiquity, therefore, mainly from the point of view of classicism. It is known that in Renaissance classicism, particularly in Italy, there was a merger of Christian beliefs from a purely classical pagan ideals. Since then originates the assumption that the origin of Christianity was due to the synthesis of Greek philosophy with Jewish belief. But this assumption is eliminated simply by the fact that, on the one hand, in Greek philosophy is evident the properties of a reasonable human spirit - why humanism is the essence of this philosophy. On the other hand, the supernatural revelation that is gradually revealed in old Testament history, and then reached its greatest fulness in the New Testament, also consistent with the essential qualities of the human spirit, as otherwise it could not be. But wonderful though supernatural revelation, constituting the object and the content of sacred history, purer, more perfect and more fullness compared to the classical philosophy to reveal the idea of human sentient beings, and life, corresponding to the true destiny of man. Indeed, God the Father in the old Testament is called simply Jehovah, the Eternal. According to this new Testament explicit teaching people are intended to live for eternity and the eternal need to keep all their thoughts and care, making the idea of eternity neutral thought throughout his life, all the time subordinating that thought (do Not take care of your life... treasure in heaven; behold the fowls of the air... "the sermon on the mount"), and the most important prayer a Christian should be a prayer to heavenly Father (and pagan philosophers, the sky was a symbol of eternity). The second person of the blessed Trinity and the second image of supernatural revelation is the Logos, the Son of God, the eternal Word. The expression for the Christian it serves an Evangelical doctrine. And the Greek philosophers we find teachings about life. However, the teachings of the gospel has created a new life in humanity, and thus did not remain a mere doctrine, but is in the history of mankind as a new life, a new spirit. Therefore, finally, this doctrine was approved and 
received the force of law a new spiritual life through the influence of the spirit on the followers and heralds of humanity new life. The unclear position that Christianity is a historical fact, had in mind, you need to put in to convey the idea that the Christian doctrine has created a new life, appeared in history as a creative force, from which it receives the beginning of a new life. In this creative power of the Christian faith in the irresistible power of persuasion which was opposed by the followers of the new faith all the historical basis of the former time, to raise the struggle against them, with the greatest force open the supernatural nature of the new doctrine, the new religious faith. The creation of new life expressed in the establishment of the Church as a special body for the development of a new life, not before existed in this form. Therefore, to complete the consideration of the grounds of religious belief, namely, in the reasonable being of man, it is essential to analyze the concept about the nature of religious belief from practical. This side deserves special attention is the question of freedom of conscience, which thus should be considered in connection with the question about the Church. The unity of theoretical and practical sides of religious belief in this case is that the concept of freedom of conscience has a direct link with the relation of faith to knowledge. Condition for successful development of science rightly recognizes the freedom of research. Applying the same requirement to the region of religious faith, we come to the concept of freedom of conscience. But thing research can do and takes only a few.And religious faith is necessary for everyone and constitutes an urgent need, especially for those who are not engaged in scientific research at all. Therefore, the demand for freedom of conscience is far from being as simple as it seems to many; it can be understood differently, embrace interests that are completely heterogeneous, and therefore the question of freedom of conscience requires careful discussion. 